\title{
From creative industries to the creative place brand: some reflections on city branding in Poland
}

\author{
Sylwia Dudek-Mańkowska ${ }^{1}$ Miroslaw Grochowski ${ }^{1}$
}

Revised: 30 January 2019 / Published online: 24 August 2019

(c) The Author(s) 2019

\begin{abstract}
Contemporary cities function in a competitive environment. In order to succeed, they build their comparative advantages using various instruments. One of them is city branding. Effective branding contributes to the increase of cities' attractiveness and thus to their competitiveness in various fields. Cities with a clear, credible and attractive vision of development have better development prospects. Creativity is used often as a part of branding strategies. Some cities describe themselves as creative and this is justified by their potential. Some possess creative potential but do not present themselves as creative and use other assets for branding. The article presents results of a study whose goal was to determine whether and to what extent creativity, as a positive attribute of a city, is used in branding of cities—capitals of Polish regions. The results of the study prove that cities with a diverse base of economic development and high creative potential treat the creative sector as one of the assets. Cities undergoing restructuring of the economy treat creativity as a very important element of branding. Creativity is also used by cities whose creative potential is negligible. This proves how high the expectations associated with the image of the "creative city" are and at the same time show the lack of realism in policy making and designing branding strategies.
\end{abstract}

Keywords Place branding $\cdot$ Creative city $\cdot$ Creative place $\cdot$ Poland

\section{Introduction}

Discussions on the relationships among urban images, branding and culture have been strongly fuelled by the wellknown body of literature connected to Richard Florida's idea of the 'creative class'. Since the 1990s, many cities, including small cities, started to seriously consider the potential of branding themselves as cultural and creative cities (Vanolo 2017).

The concept of the creative city is also used as a foundation and conceptual framework for exploring the relationships between urban branding and urban development planning. To explicitly plan the creative city in the Floridian sense is also to support the development of its creative brand. Planning can then be used as an avenue for building and supporting the brand using planning documents to identify what a city is and how it can be transformed into the creative city (Miller 2016).

Sylwia Dudek-Mańkowska

s.mankowska@uw.edu.pl

1 University of Warsaw, Warsaw, Poland
In a global, competitive environment of functioning of modern cities, effective branding contributes to the increase of their attractiveness and thus to their competitiveness in various fields. In the era of globalization markets of products, services, capital, ideas or culture have blurred borders. In order to benefit from resources and goods offered, cities need to ensure that they are associated as places where these resources are located and the goods are manufactured, exchanged and consumed. Cities with a clear, credible and attractive vision of development have better development prospects because they attract the interest of consumers, tourists and investors more effectively. It is culture and creativity that are becoming more and more a core values of place brands.

The literature shows that place-based creativity fosters uniqueness and distinctiveness of that place, and draws talent and investment by improving the reputation and attractiveness of that place (Landry 2000; Mengi et al. 2017). However, the success of creative city also depends on a well-designed creativity vision and supporting strategies (i.e. place branding and place quality strategies), and attractive urban image (Vanolo 2008). 
The paper focuses on the relationships among creative economy and place branding. In the literature, there are many examples of the influence of the creative sector on the development of cities (Boccella and Salerno 2016; Cooke and Lazzeretti 2008). There are also more and more popular studies on place brand and its importance for local development (Pasquinelli 2010; Maheshwari et al. 2011), as well as studies focused on the process of place branding with use of a presence of creative industries (Evans 2015; Mengi et al. 2017). Authors of these studies argue that the creative city is an entity that could only be developed when in the city there is (a) well-developed creative sector (economy); (b) dynamic creative community (society) and (c) well-designed strategies to support creativity (policy).

The number of studies examining the relationships among elements such as creative identity (potential of creative sector), its perception and creative strategies (strategies supporting creativity in different dimensions) is limited. Therefore, we decided to conduct such a study. Its main goal was to determine whether and to what extent creativity, as a positive attribute of a city, is used in branding of cities-capitals of Polish regions. The study was designed to answer the following questions:

Q1: Whether the level of development of the creative sector in cities justifies the use of creativity in building the city's brand?

Q2: In the branding of which cities creativity plays the most important role, and which cities are perceived as creative?

Studies on creative cities and place branding are conducted at different scales. Large, well-developed cities are particularly interesting as places of location and natural concentration of creative sector activities. Our research covers 18 cities - the capitals of all Polish regions. These cities have different sizes and different economic potentials, and the level of development of the creative sector is different. Such a set of cities allows to identify differences in approaches to branding and creativity which result from local conditions.

\section{Creativity and development}

Cities are a natural environment for the development of human creativity. Creativity in some spheres of public life finds practical application in subsequent ones that are influenced by yet other creative activities. Cities are the space of a concentrated location of assets and resources that are exploited by creative individuals and organizations. The presence of such resources and the ability to use them shapes the level of creativity of the city. This level is influenced by the current conditions for the development of the creative sector and the development of the city in the past, which largely determines the expectations towards the sector and the possibility of developing its branches.

The influence of the creative sector on the development of cities results, among others, from innovations that appear in creative environment (Costa et al. 2007). Innovations in various spheres of city life as factors stimulating development and their relationship with the creative sector have been indicated, among others, by Landry (2000) and Hall (2004) who contributed to development of the idea of a creative city. The concept of "creative class" proposed by Florida and the importance of the "creative industries" in the urban economy (Caves 2002) increased interest in the creative sector as a way to restructure the city's economic development base and seek new development incentives.

Economics of creativity refers to two dimensions of produced goods (Howkins 2013). The first one consists of physical products; the second is the intangible goods being intellectual property of their producers. The first and second are the effects of the presence of the creative sector and the creative class in cities. According to Florida (2002), the competitiveness of cities increasingly depends on the size of the creative class and how cities are able to attract creative people. Analysing the role of creativity in economic development and urban success Florida came to the conclusion that talent, technology and tolerance (3Ts) are important conditions (Florida 2002). In this 3T model, Florida argued that growth is powered by creative people, who prefer places that are culturally diverse and open to new ideas, and the concentration of 'cultural capital' wedded to new products.

Hall (2004) pointed out that developing a creative and innovative city is a long and slow process. According to Storper and Manville (2006), not the skills and creativity, but the companies and the agglomeration economies are the engines of growth. From the point of view of urban development, some authors criticized Florida for supporting only the promotion of a "trendy" neighbourhood, which can negatively affect the original population living there for a long time (Peck 2005), or even supporting urban transformations that favour higher status people instead of the majority (Pratt 2008). This is also confirmed by the view that Florida basically supports a hard city image building with a kind of soft edge by encouraging the creation of a consumptionoriented cultural milieu (Pratt 2011). Martin-Brelot et al. (2009) emphasize that the geographical context of Florida's theory is obviously weak. Florida's theory does not take into account the human and personal trajectories and networks as well that creative professionals may also associate with other people and also places where they had previously lived and worked (Gáková and Dijkstra 2014).

While Florida puts the emphasis on the attraction of creative people as the secret of economic success, European policies on the creative economy consider the attraction of creative firms more important. Empirical results of 
a European research project carried out between 2006 and 2010 ('Accommodating Creative Knowledge-Competitiveness of European Metropolitan Regions within the Enlarged Union'-ACRE) confirmed that the spatial mobility and settlement of the European creative class is not so much influenced by soft factors - as advocated by Florida — but rather by personal trajectories and hard factors. Soft factors playas opposed to Florida's concept-a subordinated role. They are more important, however, in understanding how creative people become attached to a place. Not surprisingly, in the European development pattern of creative economy place, pathway (historical development of an urban region) and personal networks (place attachment and social networks), thus a 3P model, has a lot more relevance than Florida's 3T model (Musterd et al. 2010; Boros et al. 2016; Pathy 2017).

Regardless of the opinion on the validity of the R. Florida development approach, it is unquestionable that creative resources have the potential to generate economic growth and socio-economic development that lead to salary growth, job creation and can promote social cohesion and cultural diversity. The creative sector is the foundation for creating a new economic structure of the city, generating jobs in the new economic areas, and creating and developing new metropolitan functions.

Creative sector is concentrated in cities that offer proper environment for creative people and firms. This environment cannot be found everywhere, in every city (Power and Nielsen 2010). Thus, it is difficult to expect that ideas and declaration of building a "creative" city that are stated in the documents on the development strategies will be easily translated into reality. What can happen in a dynamic metropolitan city might not be available even for large industrial agglomeration or mega cities (Lorenzen and Andersen 2009). Still creativity is a tempting opportunity to change urban reality in many regions. This is also the reason why cities' governments see the creativity as an important component of city branding strategies and their image.

\section{Creativity and place branding}

Place branding has gained visibility as one of the hot topics among academics and practitioners (Hanna and Rowley 2008). This is, among others, because of its importance for building comparative advantages of cities and regions. The literature of the subject provides many perspectives and interpretations of the concept of the place's brand. Kotler has repeatedly emphasized that brands are not only mentioned in relation to specific consumer goods and services, but also to organizations, people, concepts and places (Kotler and Armstrong 2001; Kotler and Lee 2007). Place branding is a set of city features, starting with logos and slogans (Anholt 2005; Cleave and Arku 2015) to much more complex elements, such as marketing activities, quality of infrastructure, uniqueness of the place resulting from its natural and cultural assets, local policies or activities of non-governmental organizations (Hall and Hubbard 1996; Govers 2013; Kavaratzis 2005). Kavaratzis (2005) also perceives place branding as an approach to integrate, lead and give direction to management of a place.

There are also researchers who are sceptical about the place branding and its effectiveness as well as usefulness. According to Olins (1999), branding of places is always complex, controversial and questioned; Dolnicar and Mazanec (1998) note that places are not easily eligible for branding. Branding is considered a "forest of logos, slogans and messages" (Power and Hauge 2008), and also treated as an escape from substantial political projects (Olins 1999) and an attempt to hide ineffective initiatives and actions under brilliant slogans.

The increase in interest in branding is associated with the growing competition between places, cities, regions and countries around the world (Baker and Cameron 2008). The growing interest of the authorities in the conscious creation of a place brand may result from the fact that self-governments are becoming more aware of how much benefits welldesigned place branding may bring to their cities and regions (Dudek-Mańkowska and Balkiewicz-Żerek 2015). An effective place branding can change the perception of a place that may be suffering from a poor image among external and internal constituents, create a common vision for the future of the community, provide a consistent representation of the place, enhance its local, regional and global awareness and position, discard unfavourable stereotypes associated with a place and make it more appealing (Prophet 2006, p. 4).

Culture and creativity are often core values of place brands. Branding views culture and creativity as a place asset: something the place has rather than something the place is (Ashworth and Kavaratzis 2015, p. 131). In this context, it is worth mentioning that city branding meets the need for sources of urban orientation and identification leading to the creation of a need to refill a fragmented space with positive meanings that can function as new sources of civic pride (Mommass 2002, p. 44).

Landry (2000) has drawn attention to the significance of creativity in modern cities and regions. He emphasizes the importance of the combination of hard infrastructure, or the network of building and institutions that constitute a city or a region and soft infrastructure as "the system of associative structures and social networks, connections and human interactions, that underpins and encourages the flow of ideas between individuals and institutions".

For development of a creative city, three components are needed: creative sector (identity), creative community (society) and appropriate strategies supporting creativity (policy) (Durmaz 2015). When identity is strong, place branding 
might be a process of sharing an existing identity with the world. The characteristics of a creative city may be in place but external audience are not aware of it-in this case, a branding exercise is more about promoting and marketing what exists rather than about creating a particular identity (Miller 2016).

As noted earlier, city marketing and place branding strategies today often stress ideas of culture and creativity to promote attractive urban images (Vanolo 2008). To build and promote attractive urban images, creative strategies are needed to provide a conceptual framework that links place management tools with the major components of creative city (Mengi et al. 2017) and focuses on the real and the imagined, the tangible and intangible - those hard and soft aspects of place (Miller 2016). Authors talk about creative elements and arguments in promotion products in many cities such as:

- The 'buzz' and creative class (Storper and Venables 2004; Vanolo 2008) -i.e. Las Vegas, New York, Turin;

- Art and culture (Ooi and Stöber 2010; Mihalis 2005) i.e. Berlin, Singapore, Barcelona;

- Creative industries (Mengi et al. 2017; Gasher 2002)— i.e. New York, Vancouver, Amsterdam;

- Iconic architecture (Sklair 2010; Brizotti-Pasquotto and Medrano 2014)—i.e. Bilbao, Sydney, Baku;

- Creative and cultural quarters (Evans 2015; McCarthy 2006)—i.e. Beijing, Toronto, Manchester.

\section{Methodology}

The goal of the study was to determine whether and to what extent creativity, as a positive attribute of a city, is used in branding cities - the capitals of Polish regions. The study was designed to provide answers to the following questions: (i) In which cities the creative potential is located? (ii) Which cities use creativity for branding? (iii) Do cities have a base in the form of creative potential (measured by the presence of creative sector) to market themselves as creative ones? (iv) In which cities the role of creativity in branding is the largest? (v) Which cities are perceived as creative?

The research covered 18 cities-the capitals of Polish regions (Fig. 1). Poland is divided into 16 regions. At the regional level, there is both central government and local government administration. The governor in the region (voivodship) is called the voivode who is the representative of the central government. On the other hand, the marshal of the region (voivodship) is a regional government administration body and the chairman of the regional board, i.e. the executive body of the regional selfgovernment. In the case of two regions, the voivode and marshal offices are located in different cities. That is why the number of the examined cities-capitals is bigger than the number of regions.

The study served to verify the following hypotheses:

H1 Creativity plays a smaller role in branding cities with a strong, diversified base of economic development.

H2 Creativity of the city is a key element in the branding of cities that have experienced a structural breakdown of the local economy.

H3 Creativity as a city's attractive feature is used in branding, regardless of the creative potential of cities.

Verification of hypotheses required the use of a variety of research methods and sources of information and data, and the use of interdisciplinary approaches in the research. A combination of qualitative and quantitative approaches encompassing all regional capital cities of Poland was used in the study. Methodology consisted of three steps: (1) identification of creative sector potential in all cities based on the national data base, (2) collection of information on perception of creativity level of cities selected for the research (nationwide survey, representative sample of 1000 respondents), (3) content analysis of branding-related documents for all cities (documents from the municipal governments).

The basic problem in studies concerning the creative sector is the lack of one universal definition of the creative sector and lack of agreement on what branches should be included in this sector. This study adopts the definition used in creative sector analysis in several Polish voivodships, according to which the creative sector includes all activities based on creativity, skill and talent, and takes into account the specificity of creative activities and stages of preparation of creative products, such as creation, production, distribution, consumption and protection (Grochowski et al. 2012). The following division of the creative sector was adopted:

- creative activities of a cultural nature (culture-based activities),

- creative activities of a utilitarian nature (consumer products),

- other creative activities with extensive use of knowledge ( $R \& D$ sector),

- activities within the creative sector environment (institutional environment).

The adopted definition refers to the definition coined by the British Ministry of Culture, Media and Sport (DCMS) as well as to the five stages of creating cultural goods proposed by UNESCO, such as creation, production, distribution, consumption and protection. In the adopted definition, cultural goods are understood as products of culture in the 


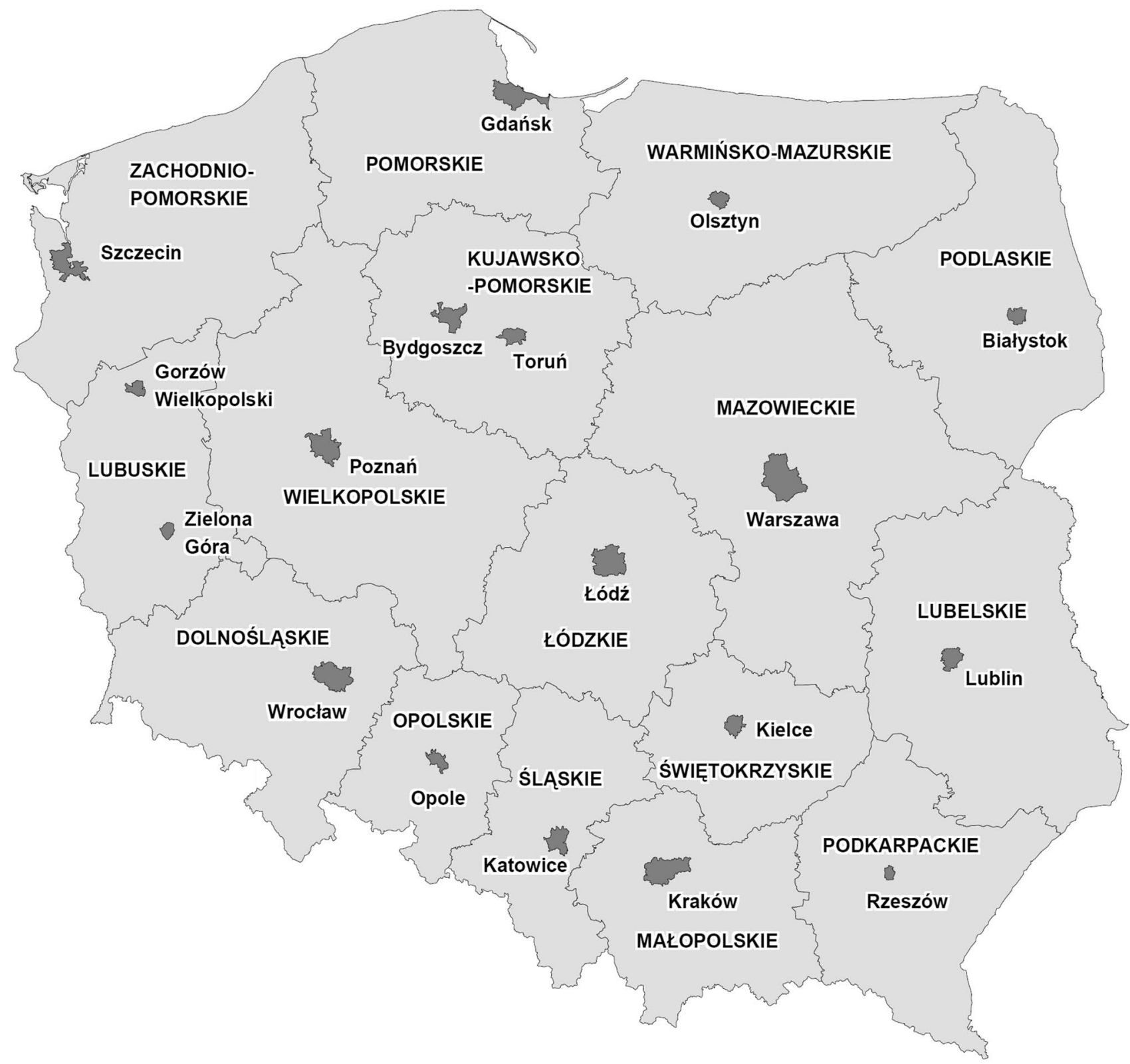

Fig. 1 Administrative division of Poland; cities—capitals of regions (voivodships). Source Central Statistical Office Poland

form of either specific products or inspirations that are used in the process of preparation of a creative product (in different phases of this process).

In many studies, the creative sector includes, above all, creative industries of a cultural and utility nature (including KEA 2006). In the adopted methodology, however, it was decided to include in the analyses activities with intensive use of knowledge, thus referring to the concepts of Florida (2002), Hartley (2005) and Musterd et al. (2007). The sector also includes university-level education institutions. In some studies, they are treated as a separate creative sub-sector of activities related to copyright. However, it was decided that organizations for the collective management of copyrights of authors should be included in the creative sector institutional environment group. These organizations are not creators but they only represent the interests of creative individuals.

In the applied approach, it is important to separate creative activities of cultural nature from those of utilitarian nature. Both subsectors clearly differ in the nature of the manufactured products. The applied approach allowed for a more detailed analysis of the condition of the sector, its diversification and development potential. According to the applied approach, activities in the sphere of culture are treated as the core of the creative sector (Table 1). Creative 
Table 1 The concept of the creative sector used in the study

\begin{tabular}{llll}
\hline Creative sector & & & \\
\hline Culture-based activities & Consumer products & R\&D sector & Institutional environment \\
\hline literature & Advertising & ICT & Cultural institutions \\
Visual arts & Architecture & R\&D & Art and antiques trade \\
Crafts & Design \& fashion & & Higher education institutions \\
Film and video & Publishing & & Copyright industries \\
Music & Radio \& television & & \\
Performing arts & software & & \\
Photography & & \\
\hline
\end{tabular}

activities of cultural nature include those activities that have roots in creativity, skills and human talent but at the same time are associated only with the production of creative products. These are, therefore, industries such as literature, visual arts, arts and crafts, film and video, musical activities, performing arts, photography.

Within the creative sector, in addition to creative activities of cultural nature, there are also creative activities of utilitarian nature and creative activities leading to the fabrication of products based on knowledge. Activities of utilitarian nature include industries that primarily produce commercial products, such as advertising, architecture, design and fashion design, publishing, radio and television, as well as computer software.

The third group includes industries with extensive knowledge utilization including research and development as well as information and communication technologies (ICT, R\&D). The fourth group contains activities carried out around the creative sector. It includes cultural institutions, universities, media, entities involved in the trade of art and antiques, as well as organizations for the collective management of copyrights of authors. These entities play an important role in the functioning of the creative sector, including sharing the resulting final products.

The aim of the first stage of the research procedure was to determine the size and structure of creative sector entities in cities and to identify its potential. For the purpose of the study, data on the number of entities in the REGON database in selected subclasses of PKD 2007 (Polish classification of economic activities) corresponding to defined industries of the creative sector were obtained from the Statistical Office in Warsaw. The data enabled the analysis of the spatial concentration of the creative sector and its specific branches of individual industries in the examined cities as of December 31 st 2016.

In the study, a location quotient (LQ) was used to diagnose the creative specialization of cities. The location quotient is often used in research on concentration of the creative sector (Chapain et al. 2010; Lazzeretti et al. 2009; Bagwell 2008; Trippl et al. 2013; Boix et al. 2016). Generally, a location quotient (LQ) is a ratio between a sector's share in the regional economy (a creative sector in this case) and its share in the national economy. The LQ for the creative sector was obtained from the following formula: $\mathrm{LQ}=(\mathrm{Eir} / \mathrm{Er}) /(\mathrm{Ein} / \mathrm{En})$, where Eir represents the number of business entities in the sector and region $\mathrm{r}, \mathrm{Er}$ - the total number of business entities in the region r, Ein-the number of business entities in the sector and in the country, and En-the total number of business entities in the country. The location quotient (LQ) may have the following values: $>1$, $1,<1 . \mathrm{LQ}=1$ means that a given type of activity in the analysed region is at the national average level. $L Q>1$ means that the region is characterized by a relatively higher activity in terms of the examined feature, and hence constitutes the regional specialization. A high level of specialization is usually referred to when $\mathrm{LQ}>1.25$.

The next step of the study was the identification of Polish cities perceived as creative. The study of city perception was conducted on a representative sample of 1000 inhabitants aged $15+$. Respondents were from all Polish regions, women predominated (52\%), 11\% were children (aged under 18 years) and $19 \%$ were people in the older age groups $(65+)$.

The survey was implemented using the CAPI technique in December 2015. The questionnaire consisted of two questions that respondents had to answer in a set format. Firstly, the respondents were asked which Polish city could be considered as a creative city; it was an open-ended question. The respondents could indicate a maximum of three cities. Secondly, they assessed the creativity of the each examined cities on a scale of 1 to 5; it was a closed-ended questions.

The third step was an analysis of branding-related documents available from the municipal governments for all the cities covered by the study. A content analysis of documents such as branding strategies, image creation strategies, promotion and communication strategies and marketing communication strategies was conducted by using checklist that covered four sections of the creative sector:

- creative activities of a cultural nature (culture-based activities),

- creative activities of a utilitarian nature (consumer products), 


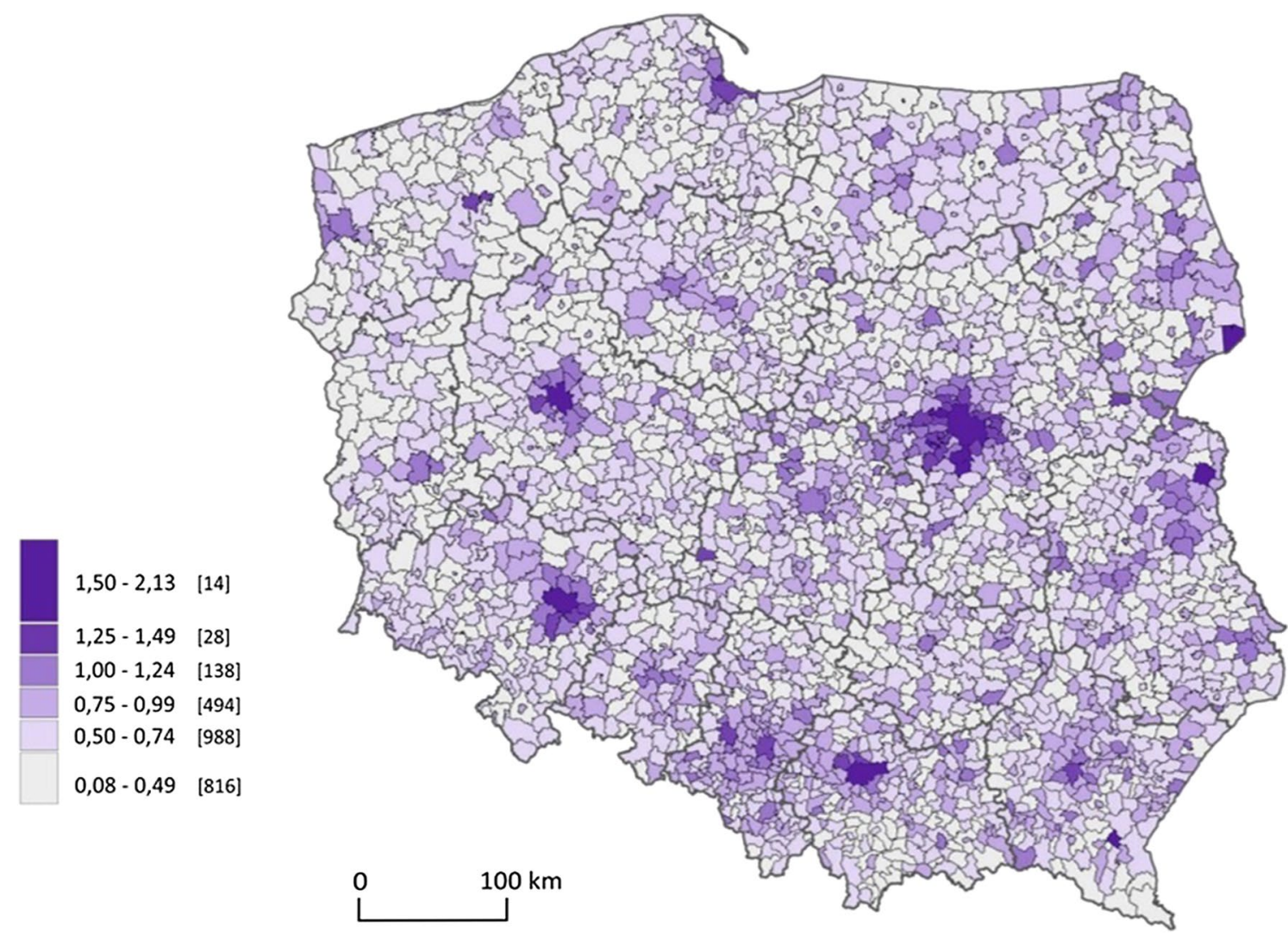

Fig. 2 LQ values calculated for the creative sector in Poland by regions and municipalities (in Polish: gmina) in 2016. Source DudekMańkowska et al. (2017)

- other creative activities with extensive use of knowledge ( $R \& D$ sector),

- activities within the creative sector environment (institutional environment).

In this step, the presence of creativity (from distinguished sections) was identified as the core value of place brands and evaluated using the scale from 0 (lack of presence) to 5 (very important value).

\section{Results}

Results of the study are presented in three sections according to the methodology adopted. The first section presents the concentration of creative industries across the Polish regional capitals. The second section focuses on an identification of Polish cities perceived as creative. The third section contains information on the presence of creativity in the place branding strategies.

\section{Concentration and differentiation of $\mathrm{Cl}$}

The research showed that the 2016 REGON database contained over 2.30 million economic entities in Poland, of which $8.8 \%$ (204.3 thousand) carried on their activities in the creative sector. One-fourth of creative industries, i.e. 52.4 thousand, were entities located in the Mazowieckie Voivodship, which indicates its significant dominance over other regions (Fig. 2). For comparison, 60.3 thousand (about $30 \%$ ) of creative sector entities operated jointly in the three voivodships: Śląskie, Małopolskie and Wielkopolskie. In contrast, the following voivodships Dolnośląskie, Pomorskie and Łódzkie totaled 32.3 thousand entities (about 20\%). In the remaining 9 voivodships, a total of nearly 50 thousand entities were located and they constituted a percentage similar to the Mazowieckie voivodship.

The vast majority of creative entities operating in Poland belong to one of the four branches: computer software (18.8\%), ICT (13.6\%), advertising (12.4\%) and architecture (10.2\%). The structure of the creative entities observed at the national level is reflected in all voivodships. Larger than the average share of a given industry is determined primarily historically and depends on the exogenous factors of urban centres. 
Table 2 LQ values for regional capital cities-creative specialization of cities

\begin{tabular}{lcccccc}
\hline City & $\begin{array}{l}\text { The number of entities in } \\
\text { the creative sector }\end{array}$ & LQ CI & LQ 1 & LQ 2 & LQ 3 & LQ 4 \\
\hline Białystok & 2211 & 1.18 & 0.98 & 1.40 & 0.87 & 1.01 \\
Bydgoszcz & 2146 & 1.00 & 0.99 & 1.02 & 1.04 & 0.92 \\
Gdańsk & 5107 & 1.44 & 1.48 & 1.60 & 1.48 & 1.06 \\
Gorzów Wielkopolski & 621 & 0.76 & 0.72 & 0.76 & 0.69 & 0.85 \\
Katowice & 2784 & 1.27 & 1.10 & 1.43 & 1.14 & 1.13 \\
Kielce & 1483 & 1.07 & 1.12 & 1.06 & 0.86 & 1.23 \\
Kraków & 10,443 & 1.60 & 1.37 & 1.82 & 1.47 & $1 . .35$ \\
Lublin & 2660 & 1.17 & 1.20 & 1.13 & 1.15 & 1.28 \\
Łódź & 5528 & 1.18 & 1.30 & 1.24 & 1.04 & 1.07 \\
Olsztyn & 1267 & 1.07 & 0.93 & 1.16 & 0.68 & 1.21 \\
Opole & 1098 & 1.17 & 1.13 & 1.16 & 1.12 & 1.246 \\
Poznań & 7616 & $1 . .53$ & 0.97 & 1.75 & 1.68 & 1.27 \\
Rzeszów & 1859 & 1.40 & 1.01 & 1.66 & 1.08 & 1.31 \\
Szczecin & 3407 & 1.11 & 0.84 & 1.22 & 1.05 & 1.08 \\
Toruń & 1557 & 1.16 & 1.27 & 1.05 & 1.04 & 1.42 \\
Warszawa & 34,611 & 2.02 & 2.13 & 2.02 & 2.54 & 1.61 \\
Wrocław & 8908 & 1.71 & 1.09 & 2.05 & 1.80 & 1.29 \\
Zielona Góra & 1151 & 1.11 & 0.84 & 1.17 & 0.89 & 1.31 \\
\hline
\end{tabular}

The examined cities operate a total of 94.5 thousand creative entities, i.e. $46 \%$ of all creative entities registered in the country. However, the creative potential of these cities varies. The strength of Warsaw is demonstrated, among others, by the location in its area of nearly $37 \%$ of companies registered in all 18 cities. Kraków and Wrocław are also clearly distinguishable. Almost $60 \%$ of companies registered in cities operate in these three cities, which makes up $26 \%$ of all creative companies in the country.

The "creative profile" of most regions is determined by companies located in their capital cities: nearly $66 \%$ of Mazowieckie companies operate in Warsaw, also Wrocław and Kraków concentrate over $50 \%$ of companies in the regions ( $53 \%$ and $52 \%$, respectively).

In order to establish the level of concentrations of firms comprising the creative sector in regional capital cities, the location quotient LQ was calculated for 18 cities (Table 2). Its values ranged between 0.76 and 2.02. The research showed only one city (Gorzów Wielkopolski) with LQ below 1.0 and 10 cities (Białystok, Bydgoszcz, Kielce, Lublin, Łódź, Olsztyn, Opole, Szczecin, Toruń, Zielona Góra) where LQ values ranged from 1.00 to 1.25 ; in the remaining 7 cities, the LQ varied between 1.25 and 2.02 (Warsaw). This last range of LQ values ( $>1.25$ ) revealed regional specialization in the creative sector. In the case of 4 cities, one can talk about very strong specialization. They are Poznań $(\mathrm{LQ}=1.53)$, Kraków (1.6), Wrocław (1.71) and Warsaw (2.02). Spatial distribution indicates a very strong relationship between the occurrence of creative sector entities and the general level of entrepreneurship as well as the rank of voivodship centres.

To identify the industry specialization of regional cities, LQ was also calculated for 4 groups of creative activities: culture-based activities, consumer products, R\&D sector and institutional environment (Table 2, Fig. 3). In the case of culture-based activities, the location quotient indicates values from 0.72 to 2.13 . Cities in which the location quotient is below 1.00 are Białystok, Bydgoszcz, Gorzów Wielkopolski, Olsztyn, Poznań, Szczecin and Zielona Góra. One can talk about the regional specialization of culture-based activities in 5 cities, i.e. Gdańsk, Kraków, Łódź, Toruń and Warsaw.

The quotient of the location of entities included in consumer products also reveals a significant difference in the distribution. The location quotient below 1 is only for Gorzów Wielkopolski. A large concentration of these industries occurs in three cities: in Kraków (1.82), Warsaw (2.02) and Wrocław (2.05).

Entities from the R\&D sector are particularly unevenly distributed in the examined cities - the location quotient varies from 0.68 (Olsztyn) to 2.54 (Warsaw). In Olsztyn, Gorzów Wielkopolski, Kielce, Białystok and Zielona Góra, the sector is underrepresented, and concentration is highest in 5 cities-Gdansk, Krakow, Poznan, Wroclaw and Warsaw. All these cities are strong academic centres.

The institutional environment entities are the most evenly distributed among these 4 categories. In most cities, the location quotient assumes values in the vicinity of 1 . Also in this case, the lowest values are for Gorzów Wielkopolski $(0.85)$ and the highest are for Warsaw (1.61). 


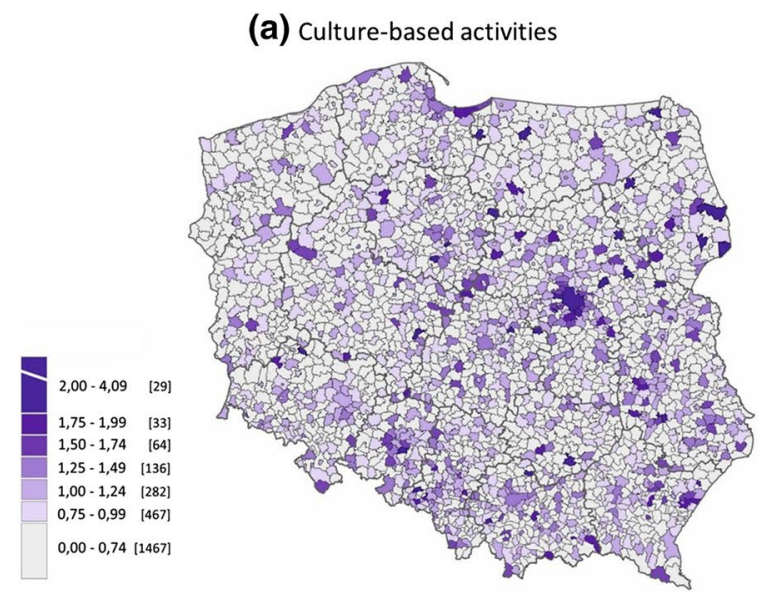

(c) R\&D sector

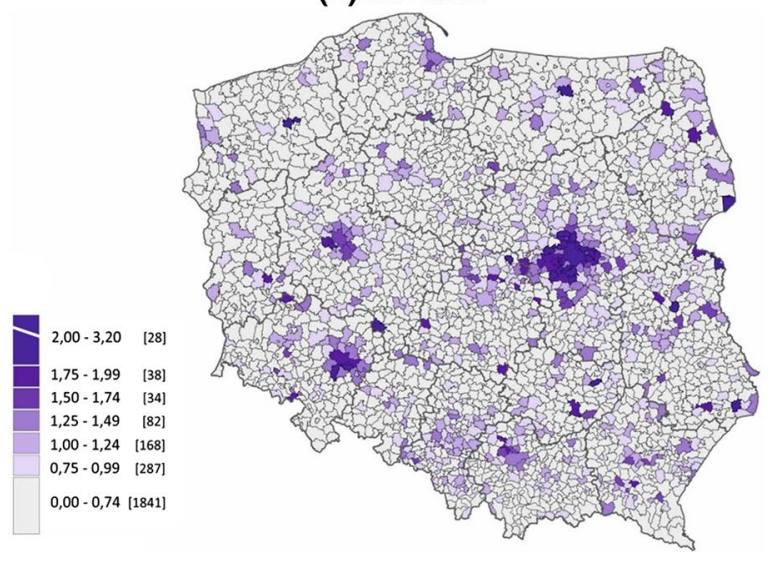

(b) consumer products

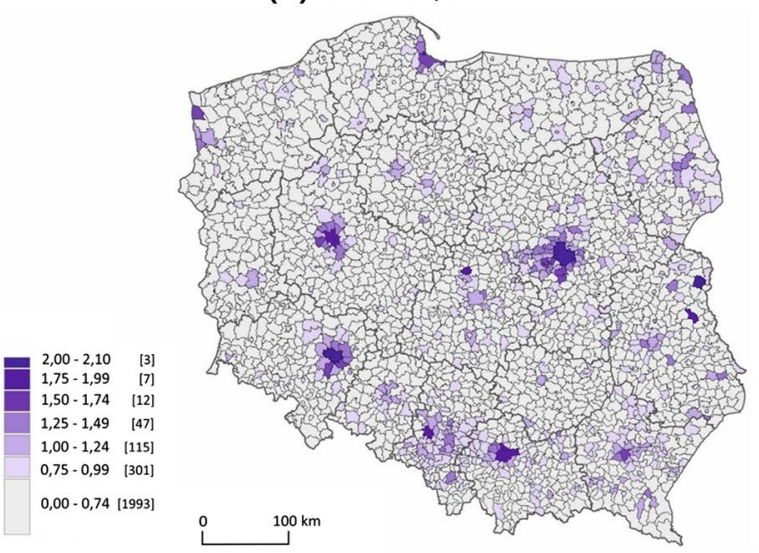

(d) institutional environment

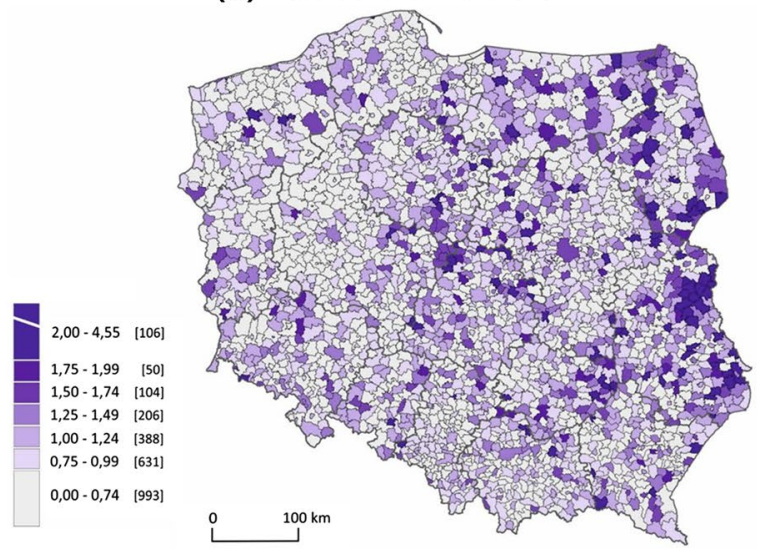

Fig. 3 LQ values for the creative industries in Poland by regions and municipalities in 2016. a Culture-based activities, $\mathbf{b}$ consumer products, $\mathbf{c}$ R\&D sector, $\mathbf{d}$ institutional environment. Source Dudek-Mańkowska et al., 2017

Some cities show a certain specialization in one branch of creative sector that is characteristic for them. This is strongly related to historical conditions as well as to the nature of the branch itself. Some branches perform exogenous functions, that is, those that are addressed to firms and consumers from outside. These branches are most often located in the largest cities that have a strong and diversified economic base. Some brunches perform endogenous functions, that is, those that are fulfilled for the needs of residents and local entrepreneurs. Such industries do not show much concentration.

The location quotient was also calculated for specific branches of the creative sector. The analysis showed creative specializations of capitals ("creative profiles of cities"). In Warsaw, all industries exhibit very high concentration; however, this is especially true in the case of film and video, musical activities and publishing activities. In Wrocław, high concentration was demonstrated by software and architecture, in Kraków-R\&D, software and musical activity, while in Poznań, R\&D, media and advertising. Also in the case of other cities where there is no such strong concentration of creative entities, specialization was observed. Among others, greater participation of arts and crafts was noted in Poznan, photography in Lublin and Łódź and cultural institutions in Torun.

\section{Perception of regional capitals as creative cities}

The study of the image of provincial cities showed that only 10 of them are perceived as creative (Fig. 4). Warsaw (22\% of indications) was most often indicated by respondents and perceived as a modern, dynamic metropolis, with the most important cultural institutions in the country. Certainly, the inhabitants' entrepreneurship and rich cultural offer influenced such perception of the capital. Łódź was ranked as the second city (17\%), promoted, as already noted, as a creative city, with film traditions and developing design and fashion. The city is perceived as the capital of the Polish movie industry. Wrocław (16\%) ranked third. In this case, the 
Fig. 4 Cities perceived as creative

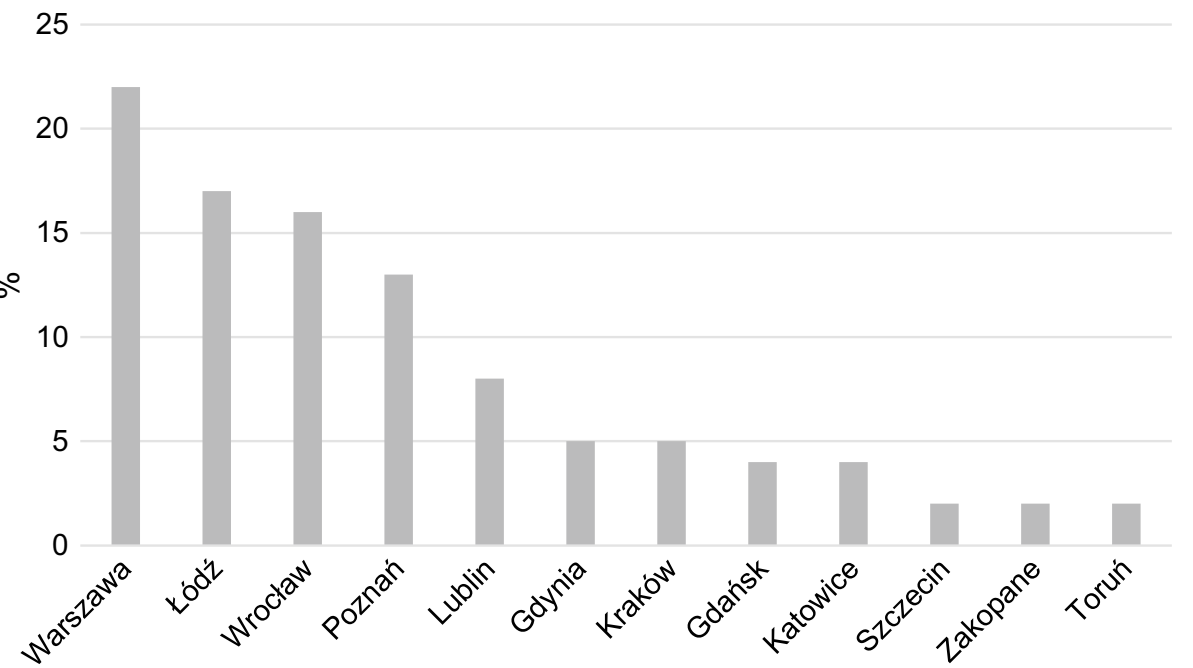

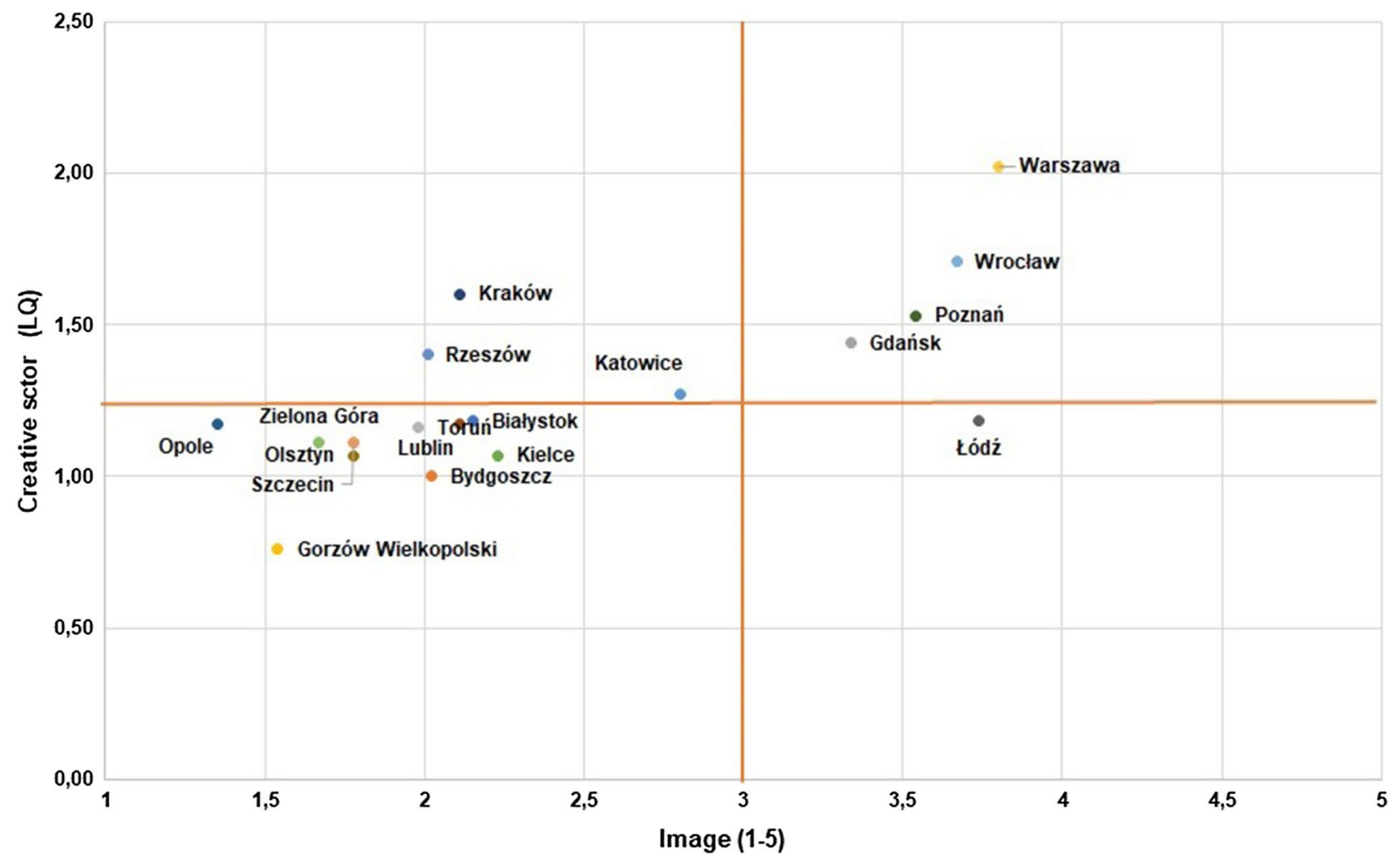

Fig. 5 Matrix — cities' creative potential and their

perception of the city as creative should be associated with campaigns accompanying the European Capital of Culture 2016. The presence of Poznan in the forefront of the ranking of creative cities (13\%) is probably the effect of a large campaign running under the slogan: "Poznań-Know-How city" promoting the city as an innovative centre (Fig. 5).

It is interesting that respondents pointed out two smaller cities: Gdynia and Zakopane. Gdynia is known for the Polish
Film Festival and promoted as dynamic, investor-friendly city. Zakopane is a ski resort in the Tatra Mountains with long history and traditions. In Bohemia, avant-garde and culture are pillars that its promotion is built on.

In addition to the free indication of cities considered by respondents to be creative, they assessed the creativity of the examined cities on a scale of 1 to 5 . The lowest rated were Opole and Gorzów Wielkopolski. Warsaw, Wrocław, 
Poznań and Gdańsk form a group of cities perceived as the most creative. At the same time, these are the cities with the strongest creative potential. Łódź is perceived as creative, although its creative potential is lower. The image of other cities is weak, as is their creative potential.

\section{Creativity in place branding strategies}

The next research step was the analysis of programmatic documents (branding strategies, image creation strategies, promotion and communication strategies, marketing communication strategies) related to the place branding. The survey showed that Łódź is the city that builds its brand to a large extent on creativity. The city's brand is positioned as a centre of creative industries. As part of the Łódź brand promotion, a film and four spots promoting the city as a Creative Industries Centre were prepared, a nationwide promotional campaign was carried out and a website was created containing, among others, a database of creative companies. The campaigns promoting the city are conducted under the slogan "Łódź creates". In the city brand, there are culture-based activities (film) as well as consumer products (design \& fashion).

Also, Wrocław uses creativity as a key asset in branding. The message that promotes this city is strongly influenced by culture and entrepreneurship. The programme documents indicated that creativity is understood broadly, not only as culture, but equally as innovation and entrepreneurship. Creativity is associated with high intellectual capital. In 2016, Wrocław was the European Capital of Culture. It was the time of very active promotion of the city as the centre of creativity and friendly environment for creative class.

An example of a city that does not stand out with the concentration of creative entities but builds its brand on culture and creativity is Opole. The National Festival of Polish Songs organized since the 1960s plays an important role in the identity of the city. When building a strategy, the city does not cut off this heritage and the image of Opole as the capital of the Polish song. On the contrary, in the idea of the Opole brand, culture is one of the key pillars, and the leading idea of the brand defined as RYTM (rhythm) refers to music.

Most of the cities surveyed treat creativity as an important element building the brand, but this is not a core value of a place brand. In the Krakow brand, an important role is played by culture-based activities and cultural institutions. Lublin culture-based activities as well as R\&D, Poznańconsumer products and innovation, Rzeszów-R\&D and Warsaw-culture. Metropolitan city like Warsaw and big cities with diversified functions like Poznań and Kraków, although they having very attractive cultural offer and strong creative sector they do not treat these assets in programmatic documents as the most important and do not display them so strongly.

There is one city-Bydgoszcz, in the group of 18 cities that does not use creativity in branding. Zielona Góra does not have any strategic documents regarding the brand, but the city does not use branding for promotion.

\section{Discussion}

The creative sector plays an important role in the contemporary development processes of cities and regions. Place branding is an attractive promotional instrument. However, the role of the creative sector varies depending on the city. The same applies to the use of creativity in branding. It turns out that the stronger the economy of the city and the more diverse the base for economic development, the smaller is the importance of creativity in branding.

The size of the city and diversification of the economic development base affect the approach to the sector as the key to success in economic development. The diversification of this base may favourably affect the ability to generate innovations and hence the diversity of development paths (Jacobs 1969). This diversity favours the development of the creative sector and increases its role in development (Landry 2000; Florida 2002, 2005; Hall 2004; Krätke 2011).

In the Polish cities that are undergoing transformation of their economies, the creative sector appears as an important component of ongoing changes (Drobniak 2008; Klasik 2011; Namyślak 2013, 2014). Cities make many efforts to attract creative capital, which, however, has a different scale and may not always be the basis for defining the city as a creative one (Przygodzki 2014). In the process of city branding, this fact is often not taken into account. This is because of popularity of creative sector as a promising solution for many cities that have experienced structural economic crisis. This popularity has an impact on the growing interest in the use of creativity in branding.

The use of creative resources requires the existence of specific conditions that can be described as the creative sphere of the city (creative field). Such a sphere consists of four main components (Scott 2006): (a) intra-city networks of specialized and complementary creators and producers, (b) local labour market and social networks that bind employees in urban space, (c) attractive urban environment, including various places of historical heritage, entertainment and social activity, and (d) institutions related to management and acting for the common good. These four components show an importance of a comprehensive approach to programming and planning of city's development for supporting development of creative sector. The same concerns the use of creativity in city branding. In the past few years, the growing popularity of application of the marketing concept to destinations' development and 
management can be observed. Especially in place branding, this application is more and more popular; however, it is often used without a holistic approach. Yet, to be effective, place branding needs to be applied in a strategic manner and should incorporate concepts that are inseparably related to this process. Among these concepts, brand positioning is the crucial one, frequently used in traditional consumer goods markets but ignored in place branding literature (Florek and Janiszewska 2011).

Creative entities bring in their human capital and their creativity, but also learn the norms, strategies and forms of the organization from the context or the environment in which they operate, which can also affect the entire creative sector.

The creative sphere of the city forms current conditions for the development of the creative sector. The development of the sector and the related specialization also depend on industries and specializations which had been functioning in the city before, and hence depend on the path of the city's development. The economic profile and innovative potential of the city depend on the main industries that are located in it (Hall 1998; Scott 2008; Storper 2013). In this sense, the development of the sector, associated specialties and the labour market influence the creative energies and possible innovative trajectories.

Staber (2008) notes that creative cities specialize, just like companies. In order to achieve a competitive advantage, ideas appearing in a given city should fit into the city's identity. This is due to the fact that the social environment is filled with semantic associations, symbolic meanings and cultural representations that reflect a basic set of ideas that can make people see a new idea as being in line with the whole set, which would not be possible if such associations did not exist (Staber 2008).

\section{Conclusions}

Development of creative sector in Poland, as in other countries, is polarized. That is why we observe concentration of creative activities in capital cities of Polish regions. Almost $50 \%$ of all creative entities registered in the country are located in these cities. However, the power of attraction of these cities varies. The strength of Warsaw-the capital city of Poland-is demonstrated by the location of nearly 37\% of creative firms registered in all cities-capitals of Polish regions.

In the group of cities covered by the research, only few can be distinguished because of their specialization as creative cities. In case of four cities, one can speak about strong specialization. These cities are Poznań $(\mathrm{LQ}=1.53)$, Kraków (1.6), Wrocław (1.71) and Warsaw (2.02). There is a correlation between the potential of creative sector and general level of entrepreneurship as well as the position of the city in the settlement system of the country.

Different creative profiles of cities result from the history of their development and the nature of their creative sectors. Regardless of how strong the creative potential is, the creativity is used by majority of cities in branding strategies. Some cities have a strong foundation for this and can certainly use this branding to stimulate their social and economic development. In some cities, in the branding strategy, creativity seems to be treated as a magic word that will change their realities.

The history of cities has an impact on the perception of the level of their creativity. From the group of cities studied, Kraków, Rzeszów and Katowice are those that have creative potential but are not perceived as creative cities. This is an important information for those responsible for their images. Warsaw - the capital of the country and the metropolis- has many resources and thus the possibility of creating its image in different ways. Łódź is an example of a city building new foundations for economic development. Fighting the deep economic crisis requires time and determination in action, the goal of which should be to strengthen creative potential.

The hypotheses formulated have been verified positively. Creativity plays a smaller role in branding cities with a strong, diversified base of economic development. The creativity of the city is a key element in the branding of cities that have experienced a structural breakdown of the local economy. The third hypothesis that says that creativity as a city's attractive feature is used in branding regardless of the creative potential of cities is also true.

In this context, at least four approaches to branding strategies can be distinguished. The first two concern situation when there is no creative potential in the city. In this situation, (a) there is a lack of creativity in branding strategy; it reflects realistic approach of city government to assets to be used for development; (b) the creativity is present in branding strategy without justification; it reflects a wishful thinking in projections of future development. The other two approaches might be distinguished in situation when the city has creative potential. In the case of cities with diversified base for economic development and diversified portfolio of functions, it may happen that other place brand attributes are preferred and creativity is not emphasized in branding strategy. When the portfolio is relatively limited, the presence of creativity in branding strategy is much better exposed.

The second approach, i.e. no assets and creative potential but presence of creativity in branding strategy, leads to conclusion that such a branding strategy might be a destructive factor and may have negative impact on local economy. Confronting the image of the city with the realities can be a sad experience and discourage tourists, people interested in settling or investors to the city. 
Open Access This article is distributed under the terms of the Creative Commons Attribution 4.0 International License (http://creativeco mmons.org/licenses/by/4.0/), which permits unrestricted use, distribution, and reproduction in any medium, provided you give appropriate credit to the original author(s) and the source, provide a link to the Creative Commons license, and indicate if changes were made.

\section{References}

Anholt, S. 2005. Brand new justice: How branding places and products can help the developing world. London: Routledge.

Ashworth, G.J., and M. Kavaratzis. 2015. Rethinking the roles of culture in place branding. In Rethinking Place Branding, 119-134. Cham: Springer.

Bagwell, S. 2008. Creative clusters and city growth. Creative Industries Journal 1 (1): 31-46.

Baker, M.J., and E. Cameron. 2008. Critical success factors in destination marketing. Tourism and Hospitality Research 8 (2): 79-97.

Boccella, N., and I. Salerno. 2016. Creative economy, cultural industries and local development. Procedia-Social and Behavioral Sciences 223: 291-296.

Boix, R., F. Capone, L. De Propris, L. Lazzeretti, and D. Sanchez. 2016. Comparing creative industries in Europe. European Urban and Regional Studies 23 (4): 935-940.

Boros, L., Sz Fabula, D. Horváth, and Z. Kovács. 2016. Urban diversity and the production of public space in Budapest. Hungarian Geographical Bulletin 65 (3): 209-224.

Brizotti-Pasquotto, G., and L. Medrano. 2014. Iconic buildings and city marketing. The central area of Sao Paulo. Revista Bitácora Urbano Territorial 24 (2): 31-40.

Caves, R. 2002. Creative industries: Contracts between arts and commerce. Cambridge: Harvard University Press.

Chapain, C., P. Cooke, L. De Propris, S. MacNeill, and J. MateosGarcia. 2010. Creative clusters and innovation. Putting creativity on the map. London: NESTA.

Cleave, E., and G. Arku. 2015. Place branding and economic development at the local level in Ontario, Canada. GeoJournal 80 (3): 323-338.

Cooke, P.N., and L. Lazzeretti (eds.). 2008. Creative cities, cultural clusters and local economic development. Cheltenham: Edward Elgar Publishing.

Costa, P., M. Magalhães, B. Vasconcelos, and G. Sugahara. 2007. A discussion on the governance of 'Creative Cities': Some insights for policy action. Norsk Geografisk Tidsskrift-Norwegian Journal of Geography 61 (3): 122-132.

Dolnicar, S. and Mazanec, J. (1998) Destination marketing: Reinventing the wheel or conceptual progress. In: Destination marketingReports of the 48th AIEST Congress, Marakech, 55-87.

Drobniak, A. 2008. Sektor kultury w procesie restrukturyzacji Aglomeracji Górnośląskiej. In Aktywność przedsiębiorcza $i$ konkurencyjność ekonomiczna miast $w$ procesie restrukturyzacji aglomeracji miejskich, ed. A. Klasik, 94-112. Katowice: Wyd. AE.

Dudek-Mańkowska, S., and A. Balkiewicz-Żerek. 2015. Siła marki miejsca. Marketing i Rynek 6: 14-23.

Dudek-Mańkowska, S., M. Grochowski, E. Murawska, K. Peszat and T. Zegar .2017. Creative industries in Mazowieckie voivodship. Warsaw: Statistical Office in Warszawa. Research paper.

Durmaz, S.B. 2015. Analyzing the quality of place: creative clusters in Soho and Beyoğlu. Journal of Urban Design 20 (1): 93-124.
Evans, G. 2015. Rethinking place branding and place making through creative and cultural quarters. In Rethinking place branding, 135-158. Cham: Springer.

Florek, M., and K. Janiszewska. 2011. Możliwości i ograniczenia pozycjonowania marek terytorialnych. Zeszyty Naukowe/Uniwersytet Ekonomiczny w Poznaniu 184: 203-221.

Florida, R. 2002. The rise of the creative class. New York: Basic Books.

Florida, R. 2005. Cities and the creative class. London: Routledge.

Gasher, M. 2002. Hollywood north: The feature film industry in British Columbia. Vancouver: UBC Press.

Gáková, Z. and L. Dijkstra. 2014. Labour mobility between the regions of the EU-27 and a comparison with the USA. Regional Focus, Regional Policy. Brussels, European Commission.

Govers, R. 2013. Why place branding is not about logos and slogans. Place Brand Public Diplomacy 9 (71): 71-75.

Grochowski, M., S. Dudek-Mańkowska, M. Fuhrmann, and T. Zegar. 2012. Sektor kreatywny w województwach pomorskim i kujawskopomorskim. Gdańsk: Agencja Rozwoju Pomorza SA.

Hall, P. 1998. Cities in civilization. New York: Pantheon.

Hall, P. 2004. Creativity, culture, knowledge and the city. Built Environment 30 (3): 256-258.

Hall, T., and P. Hubbard. 1996. The entrepreneurial city: New urban politics new urban geographies? Progress in Human Geography 20 (2): 153-174.

Hanna, S., and J. Rowley. 2008. An analysis of terminology use in place branding. Place Branding and Public Diplomacy 4 (1): 61-75.

Hartley, J. 2005. Creative industries. In Creative industries, ed. J. Hartley, 1-41. Malden: Blackwell.

Howkins, J. 2013. The creative economy: How people make money from ideas, 3rd ed. London: Penquin Books.

Jacobs, J. 1969. The life of cities. New York: Random House.

Kavaratzis, M. 2005. Place branding: A review of trends and conceptual models. The Marketing Review 5 (4): 329-342.

KEA. 2006. The Economy of Culture in Europe. Brussels: KEA.: http://www.keanet.eu/ecoculture/studynew.pdf, Accessed 17 September 2018.

Klasik, A. 2011. Kreatywne przemysły w kreatywnej aglomeracji. Biuletyn KPZK.

Kotler, Ph, and N.R. Lee. 2007. Marketing in the public sector: The final frontier. Public Manager 36 (1): 12-17.

Kotler, Ph, and G. Armstrong. 2001. Principles of marketing. New Jersey: Prentice Hall, Upper Saddle River.

Krätke, S. 2011. The creative capital of cities. New York: Wiley-Blackwell.

Landry, C. 2000. The Creative city. A Toolkit for Urban Innovators, London. London: Sterling.

Lazzeretti, L., R.B. Domenech, and F. Capone. 2009. Why do creative industries cluster? An analysis of the determinants of clustering of creative industries (No. 0902). Barcelona: Institut d'Estudis Regionals i Metropolitans de Barcelona.

Lorenzen, M., and K.V. Andersen. 2009. Centrality and creativity: Does Richard Florida's creative class offer new insight into urban hierarchy? Economic Geography 85 (4): 363-390.

Maheshwari, V., I. Vandewalle, and D. Bamber. 2011. Place branding's role in sustainable development. Journal of Place Management and Development 4 (2): 198-213.

Martin-Brelot, H., M. Grossetti, D. Eckert, O. Gritsai and Z. Kovács. 2009. Not so Mobile'Creative Class': A European perspective. GaWC Research Bulletin 306.

Mengi, O., S.B. Durmaz Drinkwater, A.C. Öner, and K. Velibeyoğlu. 2017. Place management of a creative city: The case of Izmir. International Journal of Knowledge-Based Development 8 (3): 271-291.

Mihalis, K. 2005. Branding the city through culture and entertainment. Journal Aesop 5: 1-7. 
Miller, A.J. 2016. Beyond the creative city brand: Exploring creative city-making in Winnipeg Manitoba. Department of City Planning University of Manitoba Winnipeg. Report. https://mspac e.lib.umanitoba.ca/bitstream/handle/1993/31221/miller_alexi s.pdf?sequence $=1$ (accessed 10 March 2017).

Mommas, H. 2002. City branding: The necessity of socio-cultural goals. In City branding: Image building and building images, group portraits of young architects, ed. F. Berci, H. Mommas, and K. van Synghel. Rotterdam: NAI Uitgevers.

Musterd, S., M. Bontje, C. Chapain, Z. Kovács, and A. Murie. 2007. Accommodating creative knowledge: A literature review from a European perspective. ACRE report 1. Amsterdam: AMIDSt.

Musterd, S., J. Gibney, and A. Murie (eds.). 2010. Making creative-knowledge cities: A guide for policy makers. Amsterdam: Amsterdam Institute for Social Science Research, University of Amsterdam.

McCarthy, J. 2006. Regeneration of cultural quarters: Public art for place image or place identity? Journal of Urban Design 11 (2): 243-262.

Namyślak, B. 2013. Creative city in theory. Economic and Regional Studies 6 (2): 5-21.

Namyślak, B. 2014. Sektor kreatywny w gospodarce. Gospodarka Narodowa 270 (2): 153-176.

Olins, W. 1999. Trading identities: Why countries and companies are taking on each other's role. London: The Foreign Policy Centre.

Ooi, C.S., and B. Stöber. 2010. Authenticity and place branding: the arts and culture in branding Berlin and Singapore Re-investing authenticity: Tourism, places and emotions, 66-79. Bristol: Channel View Publications.

Pasquinelli, C. 2010. The limits of place branding for local development: The case of Tuscany and the Arnovalley brand. Local Economy 25 (7): 558-572.

Páthy, Á. 2017. Types of development paths and the hierarchy of the regional centres of Central and Eastern Europe. Regional Statistics 7 (2): 124-147.

Peck, J. 2005. Struggling with the creative class. International Journal of Urban and Regional Research 29 (4): 740-770.

Power, D., and A. Hauge. 2008. No man's brand: brands, institutions and fashion. Growth and Change 39 (1): 123-143.

Power, D., and T. Nielsen. 2010. Priority sector report: creative and cultural industries. The European cluster observatory. Stockholm: Centre for Strategy and Competitiveness at the Stockholm School of Economics.

Pratt, A.C. 2008. Creative cities: The cultural industries and the creative class. Geografiska Annaler 90 (2): 107-117.

Pratt, A.C. 2011. The cultural contradictions of the creative city. City, Culture and Society 2 (3): 123-130.

Prophet, M. 2006. Branding your City Report, Online Research Report [online] http://www.ceosforcities.org. Accessed 05 June 2016.

Przygodzki, Z. 2014. Zróżnicowanie sektora kreatywnego w kontekście zdolności tworzenia miast kreatywnych w Polsce. Prace Naukowe/ Uniwersytet Ekonomiczny w Katowicach: 157-174.

Scott, A.J. 2006. Creative cities: Conceptual issues and policy questions. Journal of urban Affairs 28 (1): 1-17.

Scott, A.J. 2008. Social economy of the metropolis: Cognitive-cultural capitalism and the global resurgence of cities. Oxford: University Press.

Sklair, L. 2010. Iconic architecture and the culture-ideology of consumerism. Theory, Culture \& Society 27 (5): 135-159.

Staber, U. 2008. Network evolution in cultural industries. Industry and Innovation 15 (5): 569-578.

Storper, M. 2013. Keys to the city: How economics, institutions, social interactions and politics shape development. Princeton: Princeton University Press.
Storper, M., and M. Manville. 2006. Behaviour, preferences and cities: Urban theory and urban resurgence. Urban studies 43 (8): 1247-1274.

Storper, M., and A.J. Venables. 2004. Buzz: face-to-face contact and the urban economy. Journal of Economic Geography 4 (4): 351-370.

Trippl, M., F. Tödtling, and R. Schuldner. 2013. Creative and cultural industries in Austria. In Creative industries and innovation in Europe, ed. L. Lazzeretti, 86-102. London: Routledge.

Vanolo, A. 2008. The image of the creative city: Some reflections on urban branding in Turin. Cities 25 (6): 370-382.

Vanolo, A. 2017. City branding: The ghostly politics of representation in globalising cities. London: Routledge.

Publisher's Note Springer Nature remains neutral with regard to jurisdictional claims in published maps and institutional affiliations.

Sylwia Dudek-Mańkowska is presently the Deputy Dean for Financial and Academic Affairs and adjunct professor at the Faculty of Geography and Regional Studies, University of Warsaw, and a researcher with knowledge of theoretical and practical aspects of place branding, who specializes in studies on social transformations occurring in cities and the shaping of urban brands. She actively participates in scientific conferences and research projects, as well as various programmes, scholarships and scientific internships (Johannes Gutenberg University in Mainz, Charles University in Prague, Université Paul Valéry in Montpellier and the University of Vienna). She has received many awards and distinctions in numerous competitions (including a distinction in the competition for best doctoral dissertations awarded by the monthly "Samorząd Terytorialny" and an award in the Scholarship Competition "Modern University" for the best young doctoral graduates). She has authored numerous expert opinions in the creative sector and in the field of territorial marketing and brownfield remediation in cities.

Miroslaw Grochowski is presently a senior lecturer at the faculty of Geography and Regional Studies, University of Warsaw, and a researcher with knowledge of theoretical and practical aspects of urban development and spatial planning. From 1980 to 1990, he was with the Institute of Spatial Economy, University of Warsaw. From 1990 to 1992, he was the Deputy Director of the European Institute for Regional and Local Development EUROREG. As a visiting scholar at Kent State University (1988-1989, Kent, Ohio), Indiana University (1990-1991, Bloomington/Fort Wayne, Indiana) and Rutgers University (1992-1995), he lectured on local government reforms, decentralization and urban development in Poland and other Central and Eastern European countries to various U.S. organizations, colleges and universities. While in the U.S. from 1992 to 1994, he was affiliated with the Department of Geography at Rutgers University and served as a Project Director in International Programs Office. During the period of 1994-1995, he was the Director of this International Programs Office responsible for management and administration of major programmes of technical assistance to Poland. He has provided consulting services on issues related to urban development to the World Bank, OECD and UNDP/UN. His research activities are focused on issues related to urban and metropolitan areas development, urban governance, urban renewal and the role of creative sector in urban development. He is also the author and co-author of applied studies on Warsaw development (brownfields' development in Warsaw, economic development trends, preparation of urban renewal programme). 